\title{
VIVENDO NO MUNDO DELES: currículo a partir de um apelo geontológico
}

\author{
Thiago Ranniery \\ Universidade Federal do Rio de Janeiro - UFRJ
}

\begin{abstract}
Resumo
Este texto deriva das intenções de um projeto imersão etnográfica realizado em laboratórios de virologia e suas interfaces tradutórias com a divulgação científica. Trata-se de um ensaio tentativo e experimental sobre como as práticas científicas podem insuflar transformações imaginativas nas relações entre os diferentes seres que compartilham a Terra e no que chamamos de educação. Proponho recorrer a imagem vivendo no mundo deles a fim de interrogar imbróglios coloniais que tornam o currículo equivalente a um projeto de formação do sujeito humano. A partir de histórias entrelaçadas, o argumento explora, por um lado, como a autocracia humanista fracassa em tirar proveito da inconstância da materialidade animada do solo ao se debater contra a perda de um terreno seguro ou estável. Por outro, indica como controvérsias científicas testemunham um problema de comunicação quanto ao apelo geontológico de imprimir à educação o trabalho de coordenação e coexistência entre múltiplas histórias emaranhadas. Em diálogo com estudos feministas e queers, complicados por perspectivas neomateriais e pós-humanas, defendo a reavaliação da relação entre educação, geologia e ecologia como condição para pensar respostas éticas e políticas à destruição em curso.
\end{abstract}

Palavras-chave: Covid-19, Autocracia humanista, Histórias emaranhadas.

\begin{abstract}
This text derives from the intentions of a ethnographic immersion project carried out in virology laboratories and their translation interfaces with scientific dissemination. It is a tentative and experimental essay on how scientific practices can instill imaginative transformations in the relationships between the different beings that share the Earth in what we call education. I propose to use the image living in their world in order to interrogate how colonial troubles make the curriculum equivalent to a project for the formation of the human subject. From intertwined stories, the argument explores, on the one hand, how the humanist autocracy fails to take advantage of the inconstancy of the animated materiality of the soil when struggling against the loss of a safe or stable terrain. On the other hand, it indicates how scientific controversies testify to a communication problem regarding the geontological appeal of printing to education the work of coordination and coexistence between multiple intimate encounters. In dialogue with feminist and queer studies, complicated by neomaterial and posthuman perspectives, I defend the reassessment of the relationship between education, geology and ecology as a condition for thinking ethical and political responses to the ongoing destruction.
\end{abstract}

Keywords: Covid-19, Humanistic autarchy, Tangled histories.

ISSN 1645-1384 (online) www.curriculosemfronteiras.org 
Vamos armoçar

Sentados na calçada

Conversar sobre isso e aquilo

Coisas que nóis não entende nada

(Torresmo à milanesa, Adoniran Barbosa)

\section{Nós nos encontramos novamente em um dia ensolarado, um contraponto}

Passado um século depois, o planeta está mais uma vez em pandemia, declarou a Organização Mundial de Saúde (OMS) em 11 de março de 2020. "Mais uma vez" contém algum eufemismo de minha parte. Desde, pelo menos, a gripe de 1918, a história do século XX não deixaria desvincular que epidemias e guerras interagem em diversos níveis e em muitas porções do globo (MITCHELL, 2002). Ou ainda, para prover alguma precisão, "uma guerra bacteriológica em movimento, um fim do mundo" (KRENAK, 2018, p. 37) está em curso desde pelo menos cinco séculos de encontros coloniais. Os versos da música cantada por Vera Lynn na trilha sonora da cena final ${ }^{1}$ da explosão da bomba atômica de $D r$. Strangelove de Stanley Kubrick soam, hoje, proféticos: não sabíamos quando, nem onde, mas nos encontraremos novamente ${ }^{2}$. Diante do que parece ser uma propagação desenfreada do subtítulo do filme de 1964, - como deixei de temer a bomba e passei a amá-la ${ }^{3}$-, começo afirmando o valor da vida em todas as suas distintas condições e possibilidades. Neste momento no qual vigora a celebração da morte em voz alta, na aguda expressão de Cícero Castro (2020), tanto através da atual catástrofe sanitária ecológica global quanto através do racismo, este gesto primeiro de violência, origem do genocídio em curso nesses cinco séculos e de todos os outros que se sucederam, esta não me parece ser uma afirmação despropositada.

Faço tal consideração também porque é o modo através do qual sei e consigo, mesmo tão tateante, ecoar em palavras à sensação provada em mim após escutar o canto do SarsCov-2. Que os laboratórios de ciências biológicas se tornaram, nas últimas duas décadas, um campo espetacular da imagem é algo que a recente trabalho de Hallam Stevens (2013) demonstrou. Mais recentemente, com base em uma técnica de bioengenharia chamada de sonificação (YU; BUEHLER, 2020), o Laboratory for Atomistic and Molecular Mechanics (LAMM) do Massachusetts Institute of Technology (MIT) conferiu, através de algoritmos, a cada aminoácido da proteína spike do Sars-Cov-2 uma nota única em uma escala musical, de modo que a estrutura proteica foi convertida em uma partitura ${ }^{4}$. A proteína em questão surge na superfície do vírus e é uma máquina molecular multifuncional que medeia a entrada do Sars-Cov-2 nas células hospedeiras ao se conectar ao domínio catalítico da proteína ACE2 (MURRAY; TOMASZEWSKI; GUZIK, 2020) ${ }^{5}$. Esta última, presente principalmente em células endoteliais de vasos sanguíneos e em vários órgãos, incluindo coração, pulmões e rins, é responsável pela vasodilatação e participa do sistema de controle da pressão arterial. Os sons que se ouve - sinos, cordas vibrantes, flautas cadenciadas - traduzem as diferentes variações de forma e vibrações moleculares por oscilação de temperatura da proteína spike do Sars-Cov-2. 
Markus Buehler, engenheiro de materiais, líder da pesquisa que emaranha ciência, tecnologia e arte, escolheu como instrumento musical principal, o koto, uma caixa de ressonância de cordas dedilhadas de origem japonesa, cuja música, não raramente, entoa e incorpora um elo diacrônico conectivo com a terra e as águas (SOTOMI, 2004). O trabalho do laboratório é um exemplo de que seria impróprio não levar à sério às práticas científicas a fim de construir um interesse ético e político pela vida. Já há muito sabemos como cientistas têm uma percepção dos objetos como vivos, sejam eles organismos ou moléculas (KELLER, 1984; MYERS, 2012). Reconheço, entretanto, que objeções variadas poderiam ser levantadas ao caminho que seguirei nessas páginas por toda história passada e, não obstante, presente dos investimentos devastadores das ciências causados a um conjunto de populações minoritárias. Entretanto, a situação que nos encontramos é tão grave e de tal monta que não podemos nos dar ao luxo de não prestar atenção em como uma passagem pelas práticas científicas pode permitir, quem sabe, contraefetuá-las ${ }^{6}$ para imaginar políticas ontológicas alternativas (PAPADOULOS, 2011) que nos ajudem a resistir ao cenário de terra arrasada que se materializa, a cada dia, tenaz e insistentemente. Sobreposições entre ciência, imaginação e educação estão, portanto, no coração deste artigo.

Gosto, nesta perspectiva, de pensar que o contraponto viral, título dado à canção, por meio da construção de uma interface material-musical, na tradução um tanto livre do conceito proposto por Buehler (2020), implica a imaginação curricular em uma regra de recepção: tudo merece ser ouvido, mesmo que não possa ser visto. Como corolário, o problema que percorro não sugerirá que os conhecimentos científicos, seja quais forem, devem ser invariavelmente utilizados no currículo ou nas escolas, por professores ou estudantes com o objetivo de instrumentalizar a luta política. Por outra via, indico como as práticas científicas podem insuflar transformações imaginativas nas relações entre os diferentes seres que compartilham esta terra e, logo, no que chamamos de educação. Não sem razão, na minha escrita, este canto material-musical do Sars-Cov-2 ressoa a proximidade ética dos outros, de todos aqueles que são, na expressão Val Plumwood (2002, p. 176), "nossos outros da Terra". Seguirei, doravante, emaranhando a afirmação da vida com que chamarei, inspirado em Elizabeth Povinelli (2016), de escuta ao apelo geontológico a fim de costurar o amontado um tanto disperso, confesso, de notas escritas à esteira da pandemia de Covid-19.

Os comentários um tanto erráticos que articulo nas sessões que se seguem marcam como meu percurso ziguezagueante entre estudos curriculares, estudos de ciência e tecnologia e estudos queer carrega também um inequívoco traço pessoal. Por encontrar-me em uma espécie de roçar de fronteiras, um pesquisador em currículo, atuando em um curso de ciências biológicas, admito que, sem dúvida alguma, essa fricção deixou uma marca no meu trabalho. Não tenho motivos para negar que este artigo foi escrito por alguém para quem os vírus passaram de estatuto de inimigo a ser combatido para uma marca viva, manifestando um mundo de teias geoecológicas e espécies companheiras, compartilhando uma enrascada (HARAWAY 2008). Uma passagem que remonta ao modo como busquei escapar de ser encurralado nas metáforas bélicas da biossegurança e me desloquei sobre a proposição de Bernadette Bensaude-Vincent (2020) para sair desta arte da guerra em uma direção a uma arte da relação com os vírus, habilitadora de inventar outros modos de existência, atentos aos 
viventes e abertos às múltiplas temporalidades que lhes pertencem. Apesar do tom muitas vezes excessivamente biográfico, o quadro geral do meu argumento visa situar um conjunto de problemas comum ou tentacular - no sentido que, certa vez, lhe conferiu Eva Hayward (2010) -, à teoria curricular: como podemos pensar a educação a partir da imagem de "vivendo no mundo deles"?

Para tanto, na parte que se segue, localizo esta pergunta na minha imersão etnográfica em práticas científicas de um laboratório de virologia e na provocação aos imbróglios coloniais que associam currículo a um projeto de formação do sujeito humano. Na sessão seguinte, exploro como autocracia humanista fracassa em tirar proveito da inconstância do solo, isto é, da possibilidade de mudar de natureza ao se debater contra a perda de um terreno seguro ou estável a partir do qual tal projeto (não mais) se realizaria e que a pandemia teria colocado por terra. Encerro, por fim, apontando como as controvérsias científicas em torno dos mecanismos de ligação do Sars-Cov-2 às células hospedeiras testemunham um problema de comunicação quanto ao apelo geontológico. Se, como William Pinar (2016) sugeriu a relacionalidade da vida caracteriza a relacionalidade do currículo, se existir é "composto por material compartilhado com os outros" (PINAR, 2016, p. 21), atravessando essas sessões, está um exercício de passar a limpo um esboço tentativo e experimental de complicar os pressupostos educacionais que obliteram da renovada preocupação com noções como "vida", "subjetividade" e "diferença" as teias geoecológicas. Paradoxalmente, é precisamente quando essas teias se quebram, são perturbadas e expõem à morte social e física forçada que elas se tornam, se não visíveis, ao menos sensivelmente audíveis.

\section{Dentro da Virosfera, situando o argumento}

Vivendo no mundo deles - a imagem título deste texto me encontrou, pela primeira vez, enquanto percorria um editorial do periódico de biologia molecular, Cell. O final da apresentação do volume especial da revista compartilhava uma empolgação crescente nas ciências biológicas com a complexidade da produção dos mundos virais e encerrava com um convite, hoje, por certo, difícil de considerar: "você também deveria aprender a amar os micróbios" (CELL, 2018, p. 4). Aquele editorial estava no meio de uma centena de arquivos compartilhados por Deise, minha principal interlocutora em um laboratório de virologia, cujo trabalho de investigação venho acompanhando há dois anos. Nós nos conhecemos em uma feira de ciências em uma escola pública da cidade na qual os projetos de extensão de nossos grupos de pesquisa haviam promovido oficinas. Começamos uma conversa ali e confessei, sem muitos pudores, meu interesse em seguir, ao estilo de Bruno Latour (2011), cientistas envolvidos em pesquisas com vírus no Brasil e as traduções nos campos da divulgação científica e da educação ${ }^{7}$. Uns dias depois de nos apresentarmos, estava rodeado por estagiários e estudantes de pós-graduação especializados em genética molecular e evolução

viral, desfrutando do conforto do ar-condicionado em pleno verão na cidade do Rio de Janeiro e sentado em uma pequena mesa no canto de um sala ampla, amontada de objetos, em um espaço destinado a reuniões e recepção de visitas. 
Enquanto deambulava pelas bancadas, menos curioso com a quantidade de computadores de última geração e mais inquieto com a longa espera, Deise sugeriu que, para estar ali, precisava rever certo sentido sobre os vírus. Intrigado, perguntei por onde podia começar a estudar. Fui apresentado, de cara, a uma bibliografia básica para neófitos no campo. Ao retornar à minha casa, percorrendo o drive compartilhado via celular, tentava me virar com impacto provocado pelos rumores que entoavam daqueles textos. Por exemplo, o último relatório do Comitê Internacional de Taxonomia Viral registra 6950 espécies de vírus (ICTV, 2019). De fato, o "deles" no título do editorial, que tomei de assalto, refere-se aos mundos viriais expandidos, a Virosfera, sobre a qual escrevem Yong-Zhen Zhang, Mang Shi e Edward Holmes (2018) em um texto comentário, parte também daquele volume especial da revista Cell. Zhang, Shi e Holmes (2018) propõem nomear de "nova era virológica" (p. 168) a percepção desta experiência e criticam como ênfase naqueles vírus que causam doenças em humanos simplifica a história da vida no planeta. Os autores chegam a usar termos como "obscura matéria viral" (p. 172) para descrever o desconhecido modo de produção e interação dos vírus com a teia da vida. Ao comentar minha curiosidade com o este termo, ouvi com surpresa à sugestão da minha interlocutora: seria preciso levar esse desconhecido à sério.

De lá para cá, não tenho conseguido me livrar desta imagem nem do considerável esforço das redes de pesquisa em virologia que venho participando em escrever uma história mais robusta dos vírus desde uma interrelação entre ecologia e evolução, assumindo a diversidade e a enredamento de comunidades virais ambientais (BREITBART; ROHWER, 2005) e insistindo que a questão não é quem nós deixamos de ser quando nos encontramos com os vírus, mas "sem nossos vírus, onde nós poderíamos estar?" (ROOSSINCK; BAZAN, 2017, p. 133). Aquela biblioteca viral, o pequeno editorial de duas páginas que dela saltou e as provocações de Deise soavam me como parte de uma pragmática especulativa mais ampla e me são duplamente inspiradores. Por um lado, permitem-me engajar currículo com a crítica de Povinelli (2016) aos limites de uma tendência vitalista que toma a vida em função de um constante processo de reproduzir, nascer, crescer e morrer "cujo propósito é manter um arranjo de acumulação em vigor por meio da governança específica da diferença e dos mercados que se estende por formas de existência humanas e não humanas" (POVINELLI 2016, p. 249). Por outro, me possibilitam aproximar o trabalho da imaginação curricular da proposta de Didier Debaise e Isabelle Stengers (2016), da qual tomo a sugestão de que o sentido de uma operação especulativa é justamente suscitar possíveis.

Havia algo na expressão título - direta, feroz e delicada - que ecoava, de forma suplementar e um tanto mais evocativa, as leituras de A Acumulação do Capital de Rosa Luxemburg (1985) e A origem da família, da propriedade privada e do Estado de Friedrich Engels $(2019)^{8}$ que me lembro de ter realizado com os amigos de centro acadêmico nos cais do Rio Sergipe durante minha graduação em ciências biológicas na década de 2000. Nós nos embrenhávamos nessa literatura em meio a luta que travávamos contra a transposição do Rio São Francisco e crescemos, ali, assombrados pela tão poderosa quanto enigmática afirmação de Karl Marx (2010, p. 84) de que a "natureza é o corpo inorgânico do homem, a saber, a natureza enquanto ela mesma não é corpo humano. $\mathrm{O}$ homem vive da natureza significa: a 
natureza é o seu corpo, com o qual ele tem de ficar num processo contínuo para não morrer". Recentemente, ao comentar esta passagem, Judith Butler (2019, p. 15) sugere que há nela uma confissão do descentramento do sujeito vivo, pois oferece "uma outra maneira de pensar sobre a interdependência [...] que recusa a distinção estrita entre a condição humana e um ambiente sustentado e sustentável". É, bem verdade que, anos antes, havia sentido ecos desta formulação de Marx, mesmo com todas as ressalvas, quando me lançava com aqueles amigos por uma leitura, às vezes bastante empolgada, do desejo formulada por Deleuze e Guattari (2014) em o Anti-Édipo.

Porém, foi ao encontrar-me com o editorial da Cell que comecei a realizar a virada que estava em curso: "não [é] mais o homem como rei da criação, mas sim o homem como aquele que é tocado pela vida profunda de todas as formas e de todos os gêneros [...] eterno auxiliar das máquinas do universo" (DELEUZE; GUATTARI, 2014, p. 10). Embora não me detenha, no escopo deste texto, no trabalho de pesquisa daquele laboratório artigo, decidi abrir com esta imagem - vivendo no mundo deles - porque exemplifica o objeto central do meu argumento. Sinto como se suspendesse as marcas éticas de certa "cosmologia das cepas mutantes" (CADUFF, 2015, p. 15), justificadora da singularidade ontológica do ser humano e que é ela que está a ser acossada por um assassinato psicopata à solta. A história de uma batalha à céu aberto é simples demais para ajudar a entender a gestação monstruosa das rupturas metabólicas na qual estamos imersos, na inspiradora imagem sugerida por Camila Moreno (2018). É, sobretudo, por seu valor teórico que mantenho esta imagem comigo, por me permitir responder a fadiga crescente com o idioma militar da guerra aplicada aos encontros entre humanos e vírus (BERRIGAN, 2012) e por dar expressividade à minha interrogação a uma desgastada, mas não menos vigorosa, verdade que associa currículo ao projeto de formação do sujeito humano através da escola.

Esta "maldição milenar, que obrigava [a sociedade] a escravizar os homens para que houvesse progresso", a que Levi-Strauss (1993, p. 137) se referiu na antropologia, vastamente aplicável à educação, ambiciosa em se fazer universal, está em continuidade direta com a conversão colonial secularizada do planeta em solo territorial proprietarizável, a propósito de um neologismo sugerido por Brenna Bhandar (2018). Em resposta à pergunta do dossiê, meu argumento indica como a condição recursiva do quer que venhamos a chamar de solo como mero terreno propício para a ação humana permanece pouco problematizada, talvez porque sua planificação e sua conjuração em propriedade estável estejam muito impregnadas em nós. E, valeria relembrar, aqui, a percepção de Giorgio Agamben (2013) sobre como a máquina antropológica, que corta os laços entre o antropos e os demais viventes, transforma o humano no próprio estado de exceção ontológico, expulsando uma fração, bem sabemos nada pequena, de um tanto gente para o suposto de lado de lá por meio da expropriação e da despossesão induzida. Afirmar, entretanto, que o problema da pandemia de Covid-19 seja a dupla face entrelaçada de capitalismo tardio e colonialismo como um evento catastrófico que devorou os recursos do planeta, "transformados em resíduos e ressuscitados como parasitas" (AHUJA, 2015, p. 367) não é dizer tudo.

Aliás, devo assumir que vou rodopiar em torno da pergunta título do dossiê com um foco duplo. Não por modismo, vontade ou estilo, mas porque reconheço que tal ponderação pode, 
como notou Donna Haraway (1990, p. 1986), conter aquela "impotência intimamente relacionada para historicizar qualquer coisa que as mulheres fizessem que não seja em troca de salário". Naquela revisão de Butler (2019, p. 12) da citação de Marx, o que está em jogo é um conceito limite para "subjugar os poderes humanos por meio de modos de trabalho que presumem que a vida do ser humano e a teia da vida estão conectados desde o início". Talvez, ninguém tenha mesmo tratado como aquele editorial da Cell toda esta qualidade do "contágio viral [como] um componente essencial da criação da vida e [como] continua sendo o motor da vida" (DAHIYA, 2018, p. 44-45). Fomos como que tragados para dentro dessas teias fractais, obrigados realizar um tanto à contragosto, diga-se de passagem, que funciona à revelia de nós, para não afirmar, indiferente a nós. Em consonância, portanto, com a crítica ao excepcionalismo do antropos e a questão das mulheres efetuada por Haraway (1990), tomo alguma licença para incluir as práticas científicas da virologia no embate educacional entre as forças da vida e da morte e, ao acompanhar Natasha Myers (2015), apontar para formas de animismo imanente à lógica mecanicista que cientistas aderem tão facilmente - e incluiria nesse campo os praticantes das ciências humanas também -, dando lugar a ontologias mais vivas.

Em constante movimento e promiscuamente mesclado com diferentes sistemas culturais, vírus patogênicos mesmo quando colocam mundos em perigo, também ajudam a moldar mundos emergentes. Longe de começar com o que seriam capacidades humanas e o poder do currículo para desenvolvê-las, parto dessa nossa posição de suscetibilidade, de nossa exposição demasiada a forças que excedem a capacidade de controlar ou dar sentido pleno ao que está acontecendo. Arrastados pela escalada global e avassaladora da imprevisibilidade epistêmica e ontológica da nuvem viral sobre a qual Celia Lowe (2013) escreveu, é significativo que essa nova era virológica se inaugure por uma incerteza nebulosa, cujo instável terreno pode ser produtivo para pelos menos alguns dos desejos políticos que a imaginação curricular poderia engendrar. Trata-se de insistir como a educação se dá com e através de nossa vulnerabilidade a esse interminável vão de fricções, fissuras e alianças "dentro e entre sujeitos [em uma] topografia da subjetividade [...] multidimensional" (HARAWAY, 1990, p. 196), ao invés de figurar como mais um dos tentáculos de uma imenso polvo sem cabeça, conforme a expressão que Eric Macedo (2016) propôs para descrever a Usina de Belo Monte. Esta é uma imagem tentadora de aplicar a equivalência entre educação e empreendimento pedagógico com sua desenfreada atração por deglutir a diferença através do seu culto às "estranhas catedrais" (CAMPOS, 2012) do desenvolvimento9.

Caso educar esteja mesmo mais próximo daquele tornar-se com sobre o qual escreveu Haraway (2008), seria preciso reconhecer o incômodo com o aprisionamento do currículo ao humanismo pedagógico e psicologizante, incluindo o humanismo marxista, exercido por parte considerável da teoria curricular ${ }^{10}$. É constitutivo da educação, e este é o ponto que defendo, sermos suscetíveis à inconstância do solo volátil do qual dependemos e dentro e ao longo qual estamos vindo à tona. Buscarei demonstrar, na sessão seguinte, como o encontro entre vírus e humanos trazem essa inconstância à tona. Não seria isso que significa realizar um ato educativo que acolhe o monstro que chega, na provocação de Elizabeth Macedo (2018a), não a educação do antropos como acreditamos conhecê-lo, mas da própria vida? A 
rigor, é essa a questão de onde parte o apelo geontológico que, em "sua deformação e deslocamento" (BUTLER, 2013, p. 47), reabre a relação entre educação, geologia e ecologia frequentemente suprimida pelas "epistemologias reinantes de inteligibilidade cultural" (BUTLER, 2013, p. 47). Embora ao seguir virologistas e seus aspirantes, montando diversos dispositivos tecnológicos em redes, tenha me deparado com tentativa de construir o que Latour (2019) chamaria de próteses de fala para adicionar novas vozes ao coro, essa reabertura traz uma estranheza constitutiva, um ruído sempre há esquiva, embaraços de escuta, para torcer Latour (2019), não inteiramente representados no âmbito humano do discurso.

Por meio de histórias que envolvem esses embaraços interespecíficos ou, mais propriamente, intraespecíficos, como propõe Karen Barad (2007), espero mostrar que o solo não é simples cenário para a auto-construção do sujeito humano nem a educação a forma reflexiva desse sujeito. Em resumo, resguardo a educação o nome que se poderia a dar ao trabalho de coordenação, atenção e cuidado, de impressão de textura à coexistência da vida em paisagens temporalmente múltiplas, "dobras de espaçotempomaterializações" (BARAD, 2012, p. 40). Ao empilhar histórias nem sempre convergentes, desejo que a minha escrita possa ganhar contornos inesperados aos trazer à superfície as biografias entrecruzadas de seres em, por assim dizer, intimidade ilimitada. "Vírus são parceiros íntimos", afirmam os biólogos Marilyn Roossinck e Edelio Bazan (2017) em um recente balanço da literatura sobre vírus e ecologia. Este momento de contato devastador com mundos virais não é menos excepcionalmente íntimo e, por sua virtude, expande as compreensões de subjetividade, política e comunidade. Como Povinelli $(2006,179)$ coloca, um evento íntimo "esfolia a pele social".

\section{Perder o chão: a inconstância do solo}

"Um espectro ronda a Europa" (MARX; ENGELS, 1998, p. 7) - é a declaração célebre de abertura do Manifesto Comunista. Capital é mesmo um espectro fantasmático (DERRIDA, 1994). Esse fantasma possuiu os corpos de várias espécies e desenvolveu formas surpreendentes de reformulação geoecológica, animando seus movimentos pela paisagem, transformando organismos reais em mercadorias (MITCHELL, 2002) e assumindo, hoje, uma forma particularmente esquizofrênica (DELEUZE; GUATTARI, 2014). De tal modo, conceituar seu assombro espectral não se dá sem enfrentar as categorias maniqueístas do humanismo por sua relação vindoura com o colonialismo, exigindo uma incitação de navegar através dos efeitos planetários inter-espécies e da experiência compartilhada deles resultantes (SHARMA, 2016). De fato, o momento contemporâneo já foi mesmo caracterizado como uma atualização do colonialismo, como uma reversão neocolonial ${ }^{11}$. No entanto, é em virtude dessa fantasmagoria que, farei uso, nesta sessão, da expressão colonialismo capitalista que tomo de empréstimo de Haraway (2016) e que me atrai por não estar associada a um critério de periodização da evolução do capitalismo. 
A propósito desta escolha, retenho uma lembrança, e sei que pode parecer despropositada, sobre uma nota de Antonin Artaud (2006) em O teatro e a peste, pois elas, a nota e a peste, tem sua dose de atualidade. Artaud (2006, p, 28) afirmava, sem meias palavras, que "através da peste, e coletivamente, um gigantesco abcesso tanto moral quanto social, é vazado; e, assim como a peste, o teatro existe para vazar abscessos coletivamente". Que se note o comentário de Anäis Nin (1994) quando presenciou a conferência provida por Artaud sobre este texto na Universidade de Sorbonne, na França. Em suas palavras, seu "rosto estava convulsionado de angústia e seus cabelos, empapados de suor. Seus olhos dilatavam-se, seus músculos enrijeciam-se, seus dedos lutavam para conservar a agilidade. Fazia-nos sentir sua garganta seca e queimando, o sofrimento, a febre, o fogo de suas entranhas. Estava na tortura. Uivava. Delirava" (NIN, 1994, p. 127). Segundo seus diários, ela e Artaud tomaram um café logo após a conferência e ele magoado, sentido com as vaias e o sucessivo esvaziamento do auditório, esbravejava de fúria:

Eles sempre querem ouvir falar de; querem ouvir uma conferência objetiva sobre 'O Teatro e a Peste' e eu quero lhes dar a própria experiência, a própria peste para que eles se aterrorizem e despertem. Não percebem que estão todos mortos. A morte deles é total, como uma surdez, uma cegueira. O que lhes mostrei foi a agonia. A minha, sim, e de todos os que vivem. (NIN, 1994, p. 139)

Artaud (2006) destacava que a virulência da peste se colocava à consciência europeia de um modo brusco e dramático, uma fissura espectral que se traduzia em uma alternativa tão simples quanto sombria. Ou os "excluídos da sociedade", expressão que Artaud (1975, p. 60) usou para descrever a si mesmo no roteiro da peça $O$ jato de sangue são "gente" e, nesse caso, deveriam ser integrados à civilização, ou lhes é atribuída uma condição tão perturbadora que é outro nome para a impossibilidade criadora. Julgo que não podemos nos assegurar que estamos muito distantes desta "alternativa infernal" (PIGNARRE; STENGERS, 2011, p. 45), a qual não é bem exatamente uma alternativa, mas dois modos contíguos de aniquilamento. Com esta evocação poético-literária, não desejo, entretanto, adotar qualquer ponto de vista celebratório como se fosse preferível ou como se estivesse no mesmo nível o massacre promovido pela progressiva retirada de redes de suporte das políticas de cuidado em saúde para responder à pandemia de Covid-19 no Brasil em 2020. Apenas friso que, se a alternativa em curso for ou a integração completa ou a exclusão total, como Veena Das (2020) observou, caso se trate de aprender a conviver ou aprender morrer, trata-se fundamentalmente de não ter escolha.

Como me sinto sufocado por este encurralamento, recorro à Maurice Blanchot $(2005, \mathrm{p}$. 51) que, em um livro sobre Artaud, notou que é dessa "impossibilidade de pensar o que é o pensamento" que nasce a poesia. Em um gesto de coragem, Michel Foucault (2009), e desta vez é uma das marcas de Blanchot em Foucault, extrai de Artaud uma "materialidade do pensamento" (p. 227) a fim de para descrever "a pura e a mais desnudada experiência do exterior" (p. 227). Sigo com essas feridas de Artaud porque parece ser inegável como civilização, desenvolvimento e progresso são, em muitos sentidos, tomados como avatares 
da tarefa educacional em tornos dos quais a peste fez passar ao menos alguns abcessos. Macedo (2018b, p. 9) nomeou esses avatares de legado moderno do melhorismo que produz "a linearidade com que vivemos a história [e] permite ainda uma sensação de agência que pode levar à sua superação". A correlação de um desses termos, o desenvolvimento, em outras palavras, o "inconsciente burguês da terra" (ARTAUD, 1986, p. 39), com currículo em circunstâncias nas quais o imaginário pandêmico como um processo de projetar o fim da humanidade (LYNTERIS, 2020) parece ter se materializado de uma vez por todas e, enfim, não esperará a próxima peste a globalizar-se, é o ponto de nelgrávico que atravessa o apelo geontológico.

Em dossiê recente da revista Práxis Educativa sobre a experiência da pandemia de Covid-19 na educação, intitulado Adiando o fim da escola ${ }^{12}$, vinte diferentes artigos discutem os problemas espinhosos da exaustação docente, das políticas públicas, das políticas de indução à morte, das tecnologias na educação e da forçada transformação da forma escolar. Não obstante, a participação e a colaboração da linguagem da pedagogia, no termo de Peter Taubman (2009), na desfiguração ontológica do mundo permanecem, contudo, obliteradas. Como eixo transversal, aqueles textos apontam como, em nome de interesses tecnoeconômicos, uma política de invisibilidade é colocada em curso por meio da gramática neoliberalizante, mas também, e gostaria de acrescentar, através da prepotência da "estandardização do homo sapiens" (GALVÃO; FERRAZ, 2013) que, à guisa de um retorno do recalcado, vem definir o que é e deve ser a ação política da educação. Necessito enfrentar esse tema delicado do que vou chamar de autocracia do humano ${ }^{13}$ quando toma de assalto à imaginação curricular pela miragem do desenvolvimento. Apesar da polissemia do termo, Escobar (1995) argumenta que desenvolvimento é o nome que se pode dar ao drástico efeito da maquinaria colonial capitalista em traçar as relações entre países após Segunda Guerra Mundial que vieram a capitular o modelo urbano-industrial.

Não impressiona que biólogos, como Rob Wallace (2020), coloquem na gênese das transferências zoonóticas de vírus entre espécies o encontro feroz, em uma espécie de reverso da moeda, da promessa progressista do desenvolvimento infinito e exponencial com o limite das próprias teias da vida do planeta que o viabilizam. Embora não reproduza em profundidade o rico argumento do autor, retenho a sua afirmação de que surtos virais "estão ligados, direta ou indiretamente, às mudanças na produção ou no uso do solo associadas à agricultura intensiva" (WALLACE, 2020, p. 26). Nas palavras do coletivo chinês Chuang (2020, s/p), o "'mundo natural', incluindo seus substratos microbiológicos, não pode ser entendido sem referência a como a sociedade organiza a sua produção (porque os dois não são, de fato, separados)". Este modo de produção se faz como tal tentando - e trata-se sempre de uma tentativa nunca esgotada - cauterizar, a todo custo, qualquer contato que soe ou que faça passar um abcesso. Dito de outro modo, é como se tomasse de assalto a capacidade de escutar os sinais vívidos dos substratos microbiológicos, aqueles sobre os quais a revisão de literatura, hoje, um tanto premonitória de Yi Fan et al (2019) sobre coronavirus e morcegos na China já havia apontado. Um drible que, logo à frente, esbarra em uma toda uma rede alteritária através da qual, mesmo fantasmagoricamente, a extensão desenvolvimentista devém uma via de contato à exterioridade. 
Minha inquietação se desdobra sobre como os abscessos virais recolocam, quando não exigem, tomar a educação parte de uma "atenção aguda ao que seria radicalmente novo, sem ligação de semelhança e de continuidade com o que quer que seja [...], e atenção ao que seria o mais profundamente antigo" (FOUCAULT, 2009, p. 241). Considero que tal exigência de escutar o apelo geontológico - passa por cutucar a contínua reiteração da blindagem do currículo ao espaço "onde nenhuma existência pode se enraizar" (FOUCAULT, 2009, p. 240). E, ao ritmo de Foucault (2009, p. 237), apontar que escutar o apelo geontológico "não é somente abandonar o mundo e a distração da aparência, é sentir subitamente crescer em si o deserto no outro lado do qual [...] reluz uma linguagem sem sujeito determinável". Neste caso, subjetividade é um agenciamento de entidades (pessoas, coisas, eventos, processos, qualidades, relações) e nunca pode ser inteiramente chamada de "própria". Minha hipótese no sentido tentativo e experimental - passa por aventar como o projeto de formação do sujeito humano - o equivalente pedagógico da revolução coperniacana desde Emílio de Jean-Jacques Rousseau (1995) - não somente depende de uma metaforização da estabilidade e da segurança que sonha funcionar como dique de contenção da indeterminação, mas também de tomar por inanimada a materialidade do solo biogeofísico.

Essa dependência passa na escrita, quase sempre, pela ordem do não-dito, mas que oralmente não é raro se afirmar com todas as letras: perdemos o chão. Mel Chen (2012) nota como que a atribuição de capacidades animadas trata, antes de mais nada, de uma mediação afetiva colonial frequentemente racializada e sexualizada entre o humano e o não-humano. Quando encurralada neste "beco sem saída ontológico do organismo" (GRANT, 2006, p. 81), a imaginação curricular terminar em falhar em produzir a atenção adequada ao terreno volátil da "matéria bruta" (GRANT, 2006, p. 81) de onde a vida emerge. Como corolário, a "perda de um terreno estável", fórmula que Nigel Clark (2011, p. 163) usa para sintetizar a corriqueira sensação de impacto promovido por uma convulsão física não faz justiça, como nota o autor, a força que transforma a solidez de um abrigo em uma desculpa para a fúria exacerbada. Até mesmo uma vulnerabilidade inerente à condição humana, uma exposição constitutiva, nem de longe situa o que os vírus fazem aos corpos vivos e à própria teia da vida, isto é, a temível literalização da "desnudação além da pele" de Emmanuel Levinas (1998, p. 49).

Permito-me um pequeno exemplo. Em meditações devotadas ao devastador terremoto de Lisboa de 1755 - cataclisma que, no século XVIII, abalou os marcos filosóficos e científicos do Iluminismo -, Immanuel Kant (2005, p. 29) concluiu que "o homem não nasceu para construir cabanas eternas", assumindo, não sem demonstrar alguma inquietação, quanto "a inconstância do mundo". Kant (1991) seguiu examinando as explicações científicas para processos terrestres e celestes de sua época. As evidências, àquela altura, estavam sugerindo que a Terra, como outros planetas, passava periodicamente por revoluções e que, se haviam extinguido formas de vida, implicariam, por consequência, que outras convulsões ainda por vir poderiam obliterar de forma semelhante seus habitantes atuais. Diante do tremor da terra, Kant perturbou-se com a possibilidade da única criatura extraordinária com a capacidade de absorver e processar as produções fenomênicas da realidade física ser varrida do mapa. Mais de dois séculos se passaram, mas não é nada incomum reconhecer como se aceitou, em toda 
parte de sua difusão e em campos diversos do espectro político corrente, a injunção kantiana em torno de como o currículo deve desenvolver maneiras de apoiar o sujeito humano para extrair força de seu confronto com os poderes que ameaçam sua aniquilação.

Muito embora os ensaios sobre o terremoto e Opus Postumum sejam de momentos diferentes da obra de Kant, ambos, na sugestão de Clark (2011), guardam consigo uma relação direta entre vida, subjetividade e a geodinâmica do planeta. Tal senso ambivalente de certeza vem, sem dúvidas, sendo problematizado desde quando as viradas - cultural, linguística, pós-moderna e pós-estrutural - no campo do currículo no Brasil insuflaram-se contra o que quer "torne possível a emergência - finalmente - de um eu livre e autônomo" (SILVA, 2007, 149). Todavia, na maioria das vezes essa perturbação deve-se a forma como certas experiências humanas trouxeram indeterminação e contingência a qualquer sonho de controle normativo. Por efeito, o que pondero é como abraçar "um currículo sem fundamentos, [isto é,] admitir a política em um cenário de incertezas e sem respostas definitivas" (LOPES, 2015, p. 462) implicaria desconfiar que a base sob os pés do sujeito humano, se oferecendo como o solo de todo o pensamento e ação política não é somente outra versão para reconhecer que o "currículo é [tornado] documento de identidade" (SILVA, 2007, p. 149). A atribuição de um estatuto inanimado ao solo geofísico e suas intricadas teias químico-físicas e ecológicas vivas é o equivalente a modular este solo por meio de uma prática colonial constante que "não se processa em fazer viver, fazer morrer, deixar viver ou deixar morrer" (PUAR, 2007, p. 167). A matéria geoecológica é desabilitada, mutilada pela sua conversão em plataforma recursiva para aparecimento de um sujeito, antes que parte ativa de tornar qualquer vida vivível.

Seria tentador, por certo, afirmar que a imaginação curricular estaria, assim, invariavelmente em ressonância direta com a matriz sociocultural do tipo exportação da filosofia pós-iluminista e que, por isso mesmo, um foco menos distorcido seria conduzir ao juízo inverso, afirmando que teríamos sido absorvidos ou absorvemos tal matriz colonial. Porém, a constituição da imaginação curricular de forma alguma poderia ser decepada de maneira tão adventícia de sua "geohistória" (LATOUR, 2020, p. 52) a não ser que existissem aspectos compartilhados e internos por meio dos quais somos articulados com tal matriz. $\mathrm{O}$ problema dessa articulação é a vontade de expulsar da conversa complicada (PINAR, 2004) que constitui, em suas múltiplas fraturas, a elaboração imaginativa, não por incapacidade, mas por horror ao "morar na dissolução, onde os limites fundamentais começaram a ser desfeitos, desvendados por futuros desconhecidos" (ALAIMO, 2016, p. 2). Se há alguma saída para o inferno que fomos lançados, passará por essa queerização - designação, por certo, provisória - do pensamento, uma virada de que "estamos todos em zonas de fronteira quiméricas onde novas formas de vida estão emergindo. Somos vulneráveis uns aos outros; nossos corpos estão abertos ao planeta" (HAYWARD, 2011, s/p). Segue, logo, uma pergunta: será que quanto mais estabelecida for a suposta massa inanimada do solo melhor se exerceriam e se justificariam práticas de imaginação curricular?

Aliás, tal atribuição de estatuto inanimado ao solo se nutre de uma estranha lógica dos sonhos, típica da anedota da chaleira evocada por Freud $(2019)^{14}$, segundo a qual afirmações conflitantes e mutuamente excludentes são realizadas e para quais não importa qual se decida 
como verdadeira, o sujeito sempre sairá absolvido. Essa sensibilidade à vida ecogeofísica, a "um organismo vividamente mutante, uma abertura radical desejante, uma multiplicidade diferenciante, uma des/continuidade agencial, espaçotemporalidade dobrada e inventiva, reiteradamente materializante e promíscua" (BARAD, 2012, p. 29) é, de fato, encurralada por demandas contraditórias da equivalência entre educação, desenvolvimento e formação do sujeito, que, ao que parece, não encontra outra saída, agora, que não seja torna-se celebração apocalíptica. Já que não se pode mais andar para frente e para o alto, a única saída seria empurrar à vida constantemente para o flerte com o abismo. $\mathrm{O}$ senso de perder o chão nos afetou estranhamente por ter nos deixado à deriva de uma memória da "materialidade relacional do solo" (KRZYWOSZYNSKA; MARCHESI, 2020, p. 192), marcada de ambivalência que, talvez, seja menos doloroso calar do que performar, o que se traduz em certo sentido corrente que um dia, amanhã, as escolas reabrirão e a vida como tal será como antes.

Voltarei a este ponto nas considerações finais. Por hora, minha recorrência à relacionalidade é para embalar uma "percepção renovada das diferenças se revelarem como tais, e para a poesia ressurgir mais uma vez" (GLISSANT, 1997, p. 23) quando se vende que haveria e haverá o retorno a uma paz que só foi costurada sobre uma guerra à vida. O retorno de Glissant (1997, p. 37) à poesia é para ver "uma relação entre diferentes pessoas, lugares, objetos animados e inanimados, forças visíveis e invisíveis, o ar, a água, o fogo, a vegetação, os animais e humanos". É, assim, que a performance literária do Monólogo do vírus, uma carta escrita em primeira pessoa pelo vírus, apresenta, uma síntese poética do que chamo de apelo geontológico

Queridos humanos, parem com os vossos ridículos apelos à guerra. Parem de me lançar esses olhares de vingança. Desliguem a aura de terror com que embrulham o meu nome. Nós, os vírus, desde a origem bacteriana do mundo, somos o verdadeiro continuum da vida na Terra. Sem nós, vocês nunca teriam visto a luz do dia, nem mesmo a teria visto a primeira célula ${ }^{15}$.

Apelo é um trabalho de devolver ao currículo a poética de uma rede ignorada de relacionalidade geoecológica que, ao conviver com um desejo atroz de devastação da vida, submete a recriação dessas relações a um operador diacrítico que transforma o nexo entre vírus e humanos em uma troca virtual. Não conheço outro nome, desde quando Pinar (2004) implicou tempos, espaços e seres, que não seja currículo para condensar esse movimento, "onde não se possa considerar que todos os atores, ações e efeitos são humanos" (BARAD, 2012, p. 32). É quase como se essa troca torcesse a pergunta colocada por Henri Bergson (2005, p. 11) à beira do começo da Primeira Guerra Mundial: “o que aconteceria [...] se algum artifício diabólico fizesse [a humanidade] produzir a mecanização do espírito ao invés da espiritualização da matéria?". Arrisco-me a sonhar que o vírus poderia ser esse espírito da matéria e que tudo que não se poderia deixar acontecer ao currículo é soterrar à inconstância material da vida e não apenas revelar sua indeterminação. Claro, se por inconstância, pudermos seguir Eduardo Viveiros de Castro (2002, p. 263), "entende-se [por inconstância], 
sua autodeterminação pelo outro, sua essencial alteração". Dito de outro modo, a inconstância do solo oscila à beira da estabilidade e da instabilidade; sua relacionalidade dinâmica "é crucial para o devir sem fim do mundo que resiste tanto à acausalidade quanto ao determinismo" (BARAD, 2012, p. 40). O que se torce é a própria relação a ponto de tornar possível a mudança de natureza a cada composição relacional.

À contrapelo, os vírus encarnam não somente a prova viva do êxito ou do fracasso das políticas desenvolvimentistas urbano-industriais que reverberam ao seu modo nas experiências curriculares, mas também expõem, por meio de um excesso que transborda, uma fissura, aquela de a educação não escapa de se enredar em teias interespécies e redes geoecológicas. Em vivendo no mundo deles, está em curso um processo configurado pelos cientistas como uma história da vida do planeta e que, aparece, para mim, como um modo especulativo de repensar a história do humano, de redefinição da ação política para alimentar a vida coletiva e articular a possibilidade viver juntos. Deslocamento que é, e sei posso parecer repetitivo, sobre enfrentar a pretensão da autocracia humanista e como torna o solo propriedade colonial coextensiva para a educação produzir o espetáculo do sujeito humano. A imaginação curricular que assume a natureza humana como um dado termina por converter a educação em uma gestão promissora das catástrofes nas quais "se pode apostar que o homem se desvaneceria, como, na orla do mar, um rosto de areia" (FOUCAULT, 2001, p. 404). Nem areia nem o mar são mais os mesmos, nunca foram o campo do mesmo. Perdemos o chão.

\section{Um problema de comunicação}

Vou retornar brevemente à proteína ACE2, recentemente trazida ao centro do debate sobre a atuação do Sars-Cov-2 nas células humanas, descrita em estudo promovido por pesquisadores da Universidade de São Paulo (USP) como facilitadora da entrada do vírus na célula (PINTO et al, 2020). Em um trabalho, desta vez teórico, de modelagem proteica, inferese, de certa maneira, que mutações no gene responsável pela expressão da ACE2 produzem alterações em sua estrutura que podem permitir ou dificultar ligações com o Sars-Cov-2 (HUSSAIN et al, 2020). Também já é sabido que o mecanismo de resposta imunológica a essas ligações do vírus às células hospedeiras é aumentar consideravelmente a expressão da proteína de forma análoga ao que acontece em doenças crônicas cardiovasculares (FANG; KARAKIULAKIS; ROTH, 2020). Ainda há muito para ser explicado sobre os mecanismos de infecção do Sars-Cov-2, mas, seja de que forma for, no coração da controvérsia sobre como tratamento da Covid-19 pode se aproveitar da relação entre a proteína ACE2 e a proteína spike - já que não é possível simplesmente bloquear a ACE2, há quem aposte na indução de mutações no gene responsável por sua expressão para tornar a ligação fraca (TANAKA et al, 2020) - reside uma questão para a imaginação curricular. O caminho dos vírus não é somente imprevisível; não acontece de forma contínua e unidirecional. Existe uma comunicação ambivalente em jogo, levando-me a perguntar o que conduz a essa linguagem mútua de conversa molecular - facilitar, permitir, aumentar. 
Sinto-me tentado a aproximar esta questão do desafio formulado por Barad (2012) a uma visão de mundo que postula a existência de entidades discretas que apenas interagiriam umas com as outras, no qual mudança seria apenas o resultado de um evento (a causa), causando outro evento (o efeito). Todavia, de forma mais precisa, o que me interessa em Barad (2012) é o modo como pode-se aventar que tal comunicação de proteínas torna problemático a suposição corrente de que entidades se movem através do espaço de acordo com um fluxo linear de tempo. Forçar a imaginação curricular a reconsiderar o solo inanimado do projeto de formação do sujeito humano é implicá-lo temporalmente em teias geoecológicas cacofônicas em que "corpos compartilham metabolismos reprodutivos, cruzando escalas, espécies e sistemas (AHUJA, 2015, p. 368). É, pois, importante enfatizar que o momento contemporâneo é, em especial, politemporal, isto marcado pela coexistência de práticas e afirmações que "não fazem referência a entidades individualmente existentes e determinadas, mas a fenômenos-em-seudevir, onde o devir não está ligado a uma temporalidade futura, mas a uma relacionalidade radicalmente aberta da mundificação em si mesma" (BARAD, 2012, p. 46). O escopo desse problema de comunicação expressa muito sobre a maneira como podemos nos ligar ao vírus, insistindo na criação de uma arte de alianças e composições temporalmente emaranhadas.

É que essa arte de se aliar não se dá propriamente com o vírus como se o patógeno fosse uma unidade identificável e isolada sob a lente da microscopia eletrônica. Antes, é um movimento embaralhar o tempo ao explorar o que Dipesh Chakrabarty (2015, p. 15) chamou de convergências de histórias (humana, natural e geológica) a fim de "lutar com nosso pensamento inevitavelmente antropocêntrico a fim de suplementá-lo com formas de disposição para com o planeta que não coloquem os humanos em primeiro lugar". Tomo, deste modo, a liberdade de retirar do seu contexto etnográfico a associação que Frederick Keck (2020) realiza entre virologistas e caçadores de forma que qualquer resposta ao momento que estamos vivendo não envolve apenas a preparação para o próximo desastre, "mas a preparação para a destruição dos ambientes em que os humanos co-evoluíram com outros animais e com micróbios" (KECK, 2020, p. 111). Essa é uma declaração valiosa por permitir evocar uma reorientação do imaginário curricular através do qual é subordinado "a longa temporalidade das ecologias" (KECK, 2010, p. 110) ou, para dizer de outro, aos ritmos espaço-temporais emergentes e disruptivos dos outros seres e entes da Terra. Isso nota a educação de uma feição, talvez, pouco ressaltada: o modo como tornar-se com outros se insere em meio a relações ecológicas multiespecíficas e em tempos biogeoquímicos, o que envolve obrigações com reconfigurar os efeitos materiais do passado e do futuro.

Não se trata fazer pouco caso com futuro, ao contrário, "o ponto é que o passado nunca esteve simplesmente lá para começar e o futuro não é simplesmente o que se desdobrará" (BARAD, 2012, p. 44). O exercício de recorrer ao animismo inscrito nas práticas científicas da virologia para antecipar um futuro imprevisível ao considerar os "acontecimentos queers do mundo" (BARAD, 2012, p. 44) que já estão em curso. Em meu argumento, educar só se faz ao engrenar o que poderíamos chamar de máquina queer do mundo, isto é, o trabalho experimentar "a natureza agencialmente intra-ativa (isto é, performativa e queer) de seu devir" (BARAD, 2012, p. 33). Histórias, tempos, ritmos e ciclos são retrabalhados e dobrados através de práticas relacionais de diferenciação e produção de mundos e, parece-me, é este o nome 
deste trabalho é podemos chamar a educação. Minha insistência em um problema de comunicação não é porque não podemos ou não conseguimos ouvir os vírus. $\mathrm{O}$ apelo geontológico recoloca a educação sob o campo de uma criação compartilhada e de uma experiência de relacionar-se com regimes semióticos-materiais (HARAWAY, 1990) de uma teia fractal da vida, que, se não evitam o pior, ecoam os sinais de histórias recalcitrantes enquanto se tateia responder a destruição em curso.

Passamos do tempo de conversas de salas de jantar, ocupadas em nascer e morrer, tal como repete a música de Panis et circenses de Os mutantes. Se não somos ou se não podemos mais ser essas pessoas, é porque seria preciso colocar a vida diante da complexa geoecologia política, desde os microprocessos às interações em escala global entre solos, atmosferas e oceanos e produzir, quem sabe, próteses que selam "um pacto com a multidão" (PRECIADO, p. 2018). E, se me demorei tanto em assinalar a diferenciação entre os vírus versus seres humanos como um contraste dinâmico, que é constrangido pelo idioma da guerra, foi em virtude de um aspecto intrínseco da "erosão das civilizações" (MONTGOMERY, 2008) ser esse de colocar a imaginação curricular diante de uma outra política de resposta. Uma política que expande o entendimento de obrigação de responder quando confere a esta situação o poder de forçar parar para pensar (STENGERS, 2018). Nisso, continua Stengers (2018), a formulação de um problema nunca pode ser dissociada de um oikos, isto é, de um meio ou ambiente que requer um ethos específico.

Apelo geontológico contempla, pois, algo mais do que nos informa nossa compreensão sobre o caráter individual ou coletivo do chão que perdemos. O problema de comunicação complica à relacionalidade ao trazer o intangível e ininteligível imbricados nessa temporalidade enovelada. À essa altura, desejo frisar que esse "algo a mais" não é tanto inserir o detalhe do quer que se venha a chamar de "não-humano" na educação. O simples movimento de ampliação ainda deixaria em aberto à questão da responsabilidade. Estou, por certo, me apropriando da noção de difícil tradução, viral response-hability, algo como habilidade de resposta viral, proposta por Haraway (2016) e o deslocamento que realiza na infecção viral do campo destruição. Os vírus não deixam furtar de explicar "a lembrança dessas ligações bióticas [e abióticas] das quais somos parte" (Villaça, 2020, p. 48). Vírus são um transmissor de informações entre diferentes seres, entre seres e o ambiente, permitindo saber como estão interligados, uma espécie de lembrete das relações do "florescimento multiespécie em face às histórias terríveis" (HARAWAY, 2016, p. 116). Vírus carregam uma ambivalente memória material de tempos outros que tecem a vida e as redes de sustentação delas, destroçadas em toda área de projeção da confluência entre educação e colonialismo capitalista e instauração do currículo como a galinha dos ovos de ouro do desenvolvimento e da modernização.

Minha conversa com as práticas científicas, suponho, é apenas um convite, se não interessante, ao menos interessado, para transbordar a tarefa da habilidade do currículo responder quando já não temos mais por garantida nenhuma certeza ontológica como guia da tarefa educacional. Estou, aqui, me aproximando de Macedo (2017), sobre como a sinonímia entre currículo e reconhecimento desliza para certa proprietarização da vida (do conhecimento, da subjetividade, da cultura). Nessa conversa, os vírus carregam o inalienável 
da existência, pois se trata menos de como dispor do currículo para construir um mundo coletivo (humano, demasiado humano) do que o apelo de nos conceber e nos reconstruir como sendo parte dessas histórias emaranhadas e convergentes. Em uma virada, é a vida que nos tem. Vive-se dentro e ao longo de teias geoecológicas, de modo que, arrisco-me a sugerir, os humanos são uma propriedade dos vírus, pois os vírus têm uma vida que não pode ser reduzida às distâncias entre formas antigênicas e inimigas. Esse marco se sobressai quando meus colegas pesquisadores se põem a falar e a escrever sobre vírus e oferecem indícios que entendem o vínculo dos vírus conosco como recíproco, usando muitas vezes recursos metafóricos associados à intimidade.

Esta é uma metáfora poderosa que exige assumir que a responsabilidade de atos éticos para e com a vida é trabalhar para repensar as condições de "oferecer oportunidades para que o organismo responda" (BARAD, 2012, p. 38) como partes animadas do próprio ato de responder. É bem provável que, à essa altura, tenha carregado nas tintas de um lado fascinante das práticas científicas. Realizo, contudo, este movimento para que se possa ter em conta a violência que a ameaça à existência deriva, mesmo que não exclusivamente, da sinonímia entre o que chamamos de educação com a realização da "autobiografia da espécie humana" (DERRIDA, 2002, p. 58). Logo, o que chamo de problema de comunicação é um modo sinalizar para uma relação de imanência e reciprocidade, vetores que complicam temporalmente a história progressista de "um homem planetário, aquele que se mistura com o corpo-planeta, e que não se mostra nem um pouco interessado em seu acaso, já que suas preocupações se concentram em ecologias, economias e políticas de conversação da vida redimensionada" (SIQUEIRA, 2015, p. 222). Nem indistinção total, nem diferenciação completa, histórias emaranhadas, entrecruzadas, intra-relacionais, "paisagens radicalmente transformadas por histórias em múltiplas escalas" (TSING, 2019, p. 252). Esta é uma maneira também de evitar que o apelo geontológico seja lido como uma espécie de sonho de conservar uma natureza abstrata.

Espero ainda ter evitado professar uma teoria adâmica das práticas científicas, segundo a qual os cientistas observam os vírus e reconhecem como funcionam. Nesse golpe, tanto corre-se o risco destituir "as possibilidades de devir em relação a uma alteridade radical" (ALAIMO, 2016, p. 18) imanente às próprias práticas quanto de restituir a proprietarização do antropos por meio de sinonímias, tais como "o mundo não é nosso" ou "vírus são os donos do mundo". A propósito de torná-la inteligível, a imagem vivendo no mundo deles, em toda sua extensão, é, por esse jogo de espelhamento negativo, esvaziada. Ao navegar por laboratórios de virologia, a perspectiva oferecida a mim como navegante forasteiro não me permitiu que me situasse em um eixo perpendicular ou transcendental em aos seus múltiplos canais e às suas muitas margens. Para afirmar mais uma vez, a nova era virológica não somente ergue o dedo em riste para apontar a destruição de uma complexa teia tecnoecológica de conversações, mas sinaliza irrupções, perturbações e comunicados para que a diferença e o possível permaneçam à vista. Deles não é mesmo sinal de posse, mas de pulso criativo de instauração do mundo que se pretende roubar com a autocracia humanista.

Pareceria, assim, que o currículo operaria, de uma vez por todas, como uma força centrípeta que promove certa desaceleração dos movimentos de inserção e criação de teias 
multiespecíficas e biogeofísicas de modo que certos nódulos da autocracia humanista freariam a poética da relacionalidae. Porém, é de se notar também que essas concreções do estado do ser no seio da educação, generalizando indevidamente o que só pode ser analisado em suas circunstâncias, são invariavelmente suscetíveis de absorção pela máquina queer. Viver no mundo deles se torna audível para a educação quando o apelo dessa máquina interrompe os ritmos de que dependem o senso de orientação da atividade humana. No que se refere a resposta, não é sem razão que se pode imaginar à pandemia como uma bomba avassaladora, o sinal de que uma bomba vem explodindo o regime de coordenação das teias multiespécies, produzindo, sem pestanejar, mundos desvalidos. Porém, esta batalha não se resume a conflitos bélicos; tratava também no plano ontológico, a violência se apresenta de uma maneira difusa. Não há somente sangue jorrado no chão, a "inhaca da morte" (DANTAS, 2012, p. 126) incide sobre diferentes modos de existência.

\section{A ponto de rodar o juízo}

Abro estas breves considerações finais, desta vez, com um pequeno roubo do romance Os desvalidos de Francisco Dantas (2012). Leitura obrigatória do concurso de ingresso para universidade pública, na qual me graduei licenciatura em Ciências Biológicas, no começo dos anos 2000. Presente dado por minha avó quando estava no ensino médio e me preparava para a seleção do vestibular, o livro foi uma espécie de parceiro para quem havia crescido em um canavial, entre notícias de mortes e incêndios. Ao explorar o lugar que figuras perdedoras da guerra entre a volante policial e o bando de Lampião, a história conta que

enquanto se perseguem e se chacinam em porfiadas e sangrentas brigas, vão também esfolando a região, a saque, morte e desonra, metendo o pau na pobreza desvalida. Furam olhos, arrancam unhas, decepam os quibas e a metade da língua. A muque, arrebanhado, sofre o pacato paisano, torturado na mão de um e de outro pra falar o que não sabe, e pelo silêncio punido como espião e coiteiro do inimigo (DANTAS, 2012, p. 96).

Apanhados no susto, nosso coração estremeceu com a pandemia de Covid-19. O zumbido foi tanto que perturbou nossas cabeças, fazendo delas "uma casa de mangangá, a ponto de rodar o juízo" (DANTAS, 2012, p. 8). Foi com essa expressão que minha avó me descreveu ao telefone a sensação de viver a pandemia quando lhe atualizava do que acontecia com às escolas e às universidades públicas no Rio de Janeiro. Embargada de desassossego, naquela chamada de vídeo, ela bordava pássaros em panos de prato, derramando nas ondulações das linhas de costura apreensões quanto a morte encomendada - a expressão é dela - de um tanto de gente não ser oficiada. Na ocasião, fui surpreendido por sua ideia de bordar um pássaro para cada morte por Covid-19 no Brasil e pego imediatamente por sua preocupação. Com seu ritmo, era bem provável que fosse ultrapassada pelo crescimento vertiginoso dos números de casos. Parece-me que os pássaros bordados ressoam a afirmação 
sobre o valor das vidas perdidas daqueles que desapareceram da Terra com a qual abrir este texto. Não a realizei para me esquivar do impacto das mortes dos inumeráveis ${ }^{17}$, como se nomeou o memorial virtual dedicado à história de cada uma das pessoas mortas no Brasil por de Covid-19. A produção induzida e forçada de mundos desvalidos me assombrou durante toda escrita.

Este artigo pode ser lido como uma tessitura emaranhada de textos científicos, recursos literários, alegorias jornalísticas e enxertos filosóficos para traçar uma entrada no estudo interdisciplinar da experiência educacional "em que o currículo é vivido e experimentado" (Pinar, 2016, p. 20), e, no mesmo passo, explorar que experimentação em currículo é o trabalho de habitar um mundo desvalido, fazendo a vida ressurgir mesmo diante do seu fim. Desvalido não tem, aqui, só o sentido de não ser representado por um número, mas, sobretudo, o sentido restritivo de existência que a máquina antropológica impõe ao currículo e a educação. Pinar (2016, p. 21) realiza que o sentido de que vida tem uma duração limitada é "um fato que compartilhamos não só com todos os outros seres humanos, mas também com todas as criaturas vivas" Assim, escrevi como quem, nos limites que me cabe, responde a essa situação que assola outras tantas criaturas, sensivelmente provocado por como os vírus são considerados, em práticas científicas, um operador importante da sustentação das teias da vida, o que complica "e assombra a formação do sujeito" (PINAR, 2016, p. 25) quando se reconhece que a emergência do antropos remonta a tempos tais que, direta ou indiretamente, passam ser aqueles em vivemos, nós, no mundo deles.

Operei, portanto, em duas valências de operação argumentativa. Uma parte desdobrou o currículo a partir um apelo geontológico e como refere-se a uma ontogênese da relacionalidade da vida em devir, rebelde à grande divisão reificada e reificante, imposta pela autocracia humanista, entre orgânico e inorgânico, entre biótico e abiótico. A outra parte pretendeu se virar diante da interpelação da pergunta do dossiê como ficam nossas verdades?, afirmando como os vírus impõem um problema de comunicação, isto é, integram uma interface semiótico-material através da qual participam da "articulação de corporificação, de personificação, reconhecimento e engajamento" (PINAR, 2016, p. 33) da educação com a vida. Tratei, assim, de afastar o problema da escuta ao apelo do campo do discernimento, do entendimento ou da explicação. Para tão funestos acontecimentos, como argumentou Primo Levi (2004), não se deve mesmo buscar uma compreensão. Optei por manter como pano de fundo a trança intricada do desconhecido, o modo como o emaranhamento politemporal "exige recordar o que já aconteceu [,] às vezes não prontamente acessível" (PINAR, 2016, p. 25). Em sua intervenção, Pinar (2016, p. 25) manifestou que "esse sentido corrente de mistério na verdade" permanece de forma subterrânea em que qualquer experiência curricular, "na qual estamos todos incorporados e da qual todos participam, mesmo quando eles são retirados" (PINAR, 2016, p. 33).

A condição desta argumentação era conjurar os afetos tristes a que fui exposto pela expropriação da vida, mas, pouco a pouco, a liberação da minha capacidade de sentir me fez perceber que estou situado "dentro da barriga do monstro" (HARAWAY, 1992, p. 297). Não foram poucas às vezes nas quais me peguei dividindo dois conjuntos de ações. De um lado, o mundo animado das práticas científicas e, de outro, o mundo esgotante a que experiência 
educacional era submetida, como se não houvesse risco de contaminação, como se um fosse iluminar o outro, como se houvesse um muro a nos proteger contra a atração para aquela zona cinza, analisada por Primo Levi (2004). Zona característica dos regimes genocidas de danação da vida em que aqueles pacatos paisanos são constrangidos, para adiar a morte, a levar à cabo ações assassinas das quais a autocracia humanista não se quer nem ouvir falar, quanto mais sujar as mãos. Desconfio que a vitalidade da imaginação curricular, "a dignidade exigida para continuar, [...] a afirmação da ação possível por meio da imaginação" (PINAR, 2016, p. 36), já está na barriga do monstro e que, por isso, poderia levar em conta a banalidade do mal ambiental. Esta imagem terrivelmente luminosa que Haraway (2016) toma de Hannah Arendt para entender como um regime totalitário, um regime que tudo é possível, mutila a vida, corta relações geoecológicas e depende de uma fantasia de separação radical entre vida e não-vida. Trata-se, enfim, de perguntar como foi possível pensar a educação sem (espoliação de) mundos multiespécies, sem (expropriação da) vida orgânica e inorgânica e sem (submissão da existência a) um regime de extinção em massa.

$\mathrm{O}$ apogeu desta quimera está dado na administração constante de um corriqueiro sentido do que aconteceu ou irá acontecer a escola, que ou teria seu fim declarado por meio de impedimento de aglomerações e a consequente transferência para espaços mediados tecnologicamente, ou só demonstraria sua função caso venha a reabrir imediatamente. Em todo caso, estaríamos condenados a tomar a escola nos termos da autocracia humanista ou temos a responsabilidade e o dever ético de compreendê-la como um trabalho de criação e cultivo da vida "com o encontro dialógico através da diferença" (PINAR, 2016, p. 39)? O esforço para habitar o currículo em mundos desvalidos é o de uma luta de alianças que desejar ir até o fim.

Sou levado, por afim, a considerar que seria urgente para a imaginação curricular responder à pandemia de Covid-19 pensar a partir de duas declarações que se repetem na argumentação de Stengers (2018) em sua proposição cosmopolítica:“É preciso ser cauteloso quanto à boa vontade individual" (p. 448) e "Nós não somos confiáveis!" (p. 463). O que as tornam interessantes é que Stengers não pretende que não sejamos corruptíveis. Suas declarações estão liberadas de um confinamento na moral. O problema, como ela sustenta, passa por não sabermos do que uma criatura é capaz. Esse não saber é uma positividade, é uma abertura ao cosmos, "o desconhecido que constitui esses mundos múltiplos, divergentes” (STENGERS, 2018, p. 447) que, ela imagina, poderíamos tentar juntar à política para nos recordar que não estamos sozinhos no mundo e, não somos, por isso mesmo, detentores de um saber sobre o mundo nem seus sócios proprietários. Talvez, os versos de Adoniran Barbosa, que deixei pendurados na epígrafe, estejam mais certos do que nunca: é hora da imaginação curricular sentar na calçada e conversar sobre os desconhecidos mundos virais e aquilo que os anima, levar à sério e até as últimas consequências esse desconhecido, conversar sobre o que não se sabe nada. 


\section{Notas}

1. Refiro-me à cena do Major Kong com chapéu de cowboy eternizado pela representação do meio-oeste norte-americano, cavalgando em cima de uma ogiva nuclear em direção ao alvo. A capa do jornal Le Diplomatique parafraseou esta imagem em sua edição de maio de 2020, colocando a figura do presidente Jair Bolsonaro, desta vez, cavalgando em cima da cepa viral com um chapéu de peão em contraste com as imagens de covas vazias abertas em diversos cemitérios do país. A imagem pode ser conferida em: https://diplomatique.org.br/edicao/edicao-154/.

2. Trata-se do trecho da música We'll meet again (nós nos encontraremos novamente). No inglês: We'll meet again/ Don't know where/ Don't know when/ But I know we'll meet again some sunny day. Em tradução livre: Nós nos encontraremos novamentel Não sabemos ondel Não sabemos quandol Mas sei que nós nos encontraremos novamente em um dia ensolarado.

3. A gramática da guerra é notável, por exemplo, em um livro que, agora, se tornou um best-seller de autoria de Stefan Ujavri (2012), intitulado A história da humanidade contada pelos vírus.

4. A música pode ser escutada em: https://soundcloud.com/user-275864738/viral-counterpoint-of-the-coronavirus-spikeprotein-2019-ncov. Acesso em agosto de 2020.

5. O termo vem do inglês Angiotensin-converting enzyme 2, enzima conversora da angiotensina 2 e, designa tanto o gene quanto a proteína que ele expressa.

6. Minha inspiração, aqui, é, sem dúvidas, em Gilles Deleuze (2000) para quem contraefetuação, correndo o risco de ser deveras simplista, é dar nova forma a forças que não param de entrar em relação e que insistem ou subsistem nas coisas e nas proposições

7. Informações sobre o projeto de pesquisa que sustenta este texto foram retiradas a fim de evitar quebra de anonimato.

8. Infelizmente, não consegui localizar a versão fotocopiada das obras de Marx e Engels que faço referência e que, intuo, devem ter se extraviado nas várias mudanças de cidade que realizei. Deste modo, tive me contentar com uma versão recente dessas publicações, esperando driblar a estranheza do leitor com a data da referência.

9. Reconheço minha dívida com empreendimento de Eliane Lopes (2017) em desconstruir o valor da educação como salvação e, em parte, considero que estou apenas deslocando o argumento da autora para o meu contexto e interesse de pesquisa. De pronto, também indico que, embora a noção de desenvolvimento curricular seja invariavelmente associada à obra de Ralph Tyler, Princípios básicos do currículo e ensino, estou ponderando que a noção de desenvolvimento encontra amplo eco com a noção de formação do sujeito humano, dispersa em diferentes matrizes do pensamento curricular corrente, a despeito de aderirem ou mesmo rechaçarem a racionalidade dos princípios do autor. Um exemplo desta associação pode ser encontrado no modo como Elizabeth Macedo (2015) investigou o significante direitos de aprendizagem na BNCC.

10. Os trabalhos Gert Biesta (2013) e Tim Ingold (2018) sobre a psicologização da educação foram cruciais para chegar a essa formulação.

11. Estou fazendo a referência a uma certa matriz de pensamento sociológico brasileiro em que o termo aparece em dívida com às formulações de Celso Furtado (1992).

12. O dossiê pode ser conferido em: https://revistas2.uepg.br/index.php/praxiseducativa/issue/view/694.

13. Estou deslocando o termo autocracia energética de Célio Bermann (2012) para meus próprios interesses argumentativos.

14. Anedota conta de um amigo que acusa alguém de ter devolvido quebrada a chaleira que ele lhe havia emprestado. A resposta da pessoa é: primeiro, devolvera a chaleira intacta; segundo, que já estava quebrada quando recebeu; e, terceiro, que jamais havia pedido emprestado chaleira alguma.

15. A carta o Monólogo do vírus pode ser encontrada no site do jornal Lundi Matin em: https://lundi.am/Monologo-dovirus. Acesso em maio de 2020.

16. O Memorial dos Inumeráveis pode ser acessado em: https://inumeraveis.com.br/.

\section{Referências}


AHUJA, N. Intimate Atmospheres: Queer Theory in a Time of Extinctions. GLQ: A Journal of Lesbian and Gay Studies, n. 2-3, p. 366-385, 2015.

ALAIMO, Stacy. Exposed: Environmental Politics and Pleasures in Posthuman Times. Minneapolis: University of Minnesota Press, 2016.

ARTAUD, Antonin. O teatro e seu duplo. São Paulo: Martins Fontes, 2006.

ARTAUD, Antonin. Heliogábalo ou o anarquista coroado. In: WILLIER, Claudio. (org.). Escritos de Antonin Artaud. São Paulo: L\&PM, 1986. p. 32-53

ARTAUD, Antonin. El jet sangre. In: ARTAUD, Antonin. El ombligo de los limbos. El pesa-nervios. Buenos Aires: Ed. Aquarius, 1975. p. 34-40.

AGAMBEN, Giorgio. O Aberto. Civilização Brasileira. Rio de Janeiro, 2013.

BARAD, Karen. Meeting the Universe Halfway: Quantum Physics and the Entanglement of Matter and Meaning. Durham: Duke University Press, 2007.

BARAD, Karen. Nature's Queer Performativity. Kvinder, Køn \& Forskning, n. 1-2, p. 25-53, 2012

BENSAUDE-VINCENT, Bernadette. Guerre et Paix avec le coronavirus. Terrestres, n. 13, 30 de abril de 2020. Disponível em: https://www.terrestres.org/2020/04/30/guerre-et-paix-avec-le-coronavirus/. Acesso em: ago. 2020.

BERGSON, Henri. The Meaning of the War. Nova York: Project Gutenberg, 2015.

BERRIGAN, Caitlin. The Life Cycle of a Common Weed: Viral Imaginings in Plant-Human Encounters. Women's Studies Quarterly, v. 40, n. 12, p. 97-116, 2012.

BHANDAR, Brenna. Colonial Lives of Property. Durham: Duke University Press, 2018.

BIESTA, Gert. The Beautiful Risk of Education. Londres: Paradigm, 2013.

BLANCHOT, Maurice. O livro por vir. São Paulo: Martins Fontes, 2005.

BREITBART, Mya; ROHWER, Forest. Here a virus, there a virus, everywhere the same virus?. Trends in Microbiology, v. 13, n. 6, p. 278-284, 2005.

BUEHLER, Markus. Nanomechanical sonification of the 2019-nCoV coronavirus spike protein through a materiomusical approach. arXiv, v. 2003, 2020 (eprint). Disponível em: https://arxiv.org/ftp/arxiv/papers/2003/2003.14258.pdf. Acesso em: jul. 2020.

BUTLER, Judith. The inorganic body in the early Marx: a limit-concept of anthropocentrism. Radical Philosophy, v. 2, n. 6, p. 1-16, 2019.

BUTLER, J. O que é a crítica? um ensaio sobre a virtude de Foucault. Cadernos de Ética e Filosofia Política, São Paulo, n. 22, p. 159- 179, 2013.

CADUFF, Carlo. The Pandemic Perhaps: Dramatic Events in a Public Culture of Danger. Berkley: University of California Press, 2015.

CAMPOS, Pedro. A ditadura dos empreiteiros: as empresas nacionais na construção pesada, suas formas associativas e o Estado ditatorial brasileiro, 1964-1985. Tese (Doutorado em História) - Universidade Federal Fluminense, Niterói, 2012.

CASTRO, Cícero. Viva a morte, abaixo a inteligência! Poder 360, 2 de abril de 2020. Disponível: https://www.poder360.com.br/opiniao/governo/viva-a-morte-abaixo-a-inteligencia-cita-cicero-castro/. Acesso em jul. 2020.

CELL. Living in Their World. Cell, n. 172, p. 1137-1138, v. 2018.

CHAKRABARTY, Dipesh. The Anthropocene and the convergence of histories. In: HAMILTON, Clibe; BONNEUIL, Christophe; GEMENNE, François. The Anthropocene and the Global Environmental Crisis: Rethinking modernity in a new epoch. Routledge, 2015. p. 44-56. 
CHEN, Mel. Animacies: Biopolitics, Racial Mattering, and Queer Affect. Durham: Duke University Press, 2012.

CHUANG. Outras Fitas: Contágio Social - coronavírus, China, capitalismo tardio e o 'mundo natural'. A fita, 28 de fevereiro de 2020. Disponível em: http://afita.com.br/outras-fitas-contagio-social-coronavirus-chinacapitalismo-tardio-e-o-mundo-natural/. Acesso em: ago. 2020.

CLARK, Nigel. Inhuman Nature: Sociable Life on a Dynamic Planet. Londres: Sage Books, 2011.

DAHYIA, Annu. Before the Cell, There Was Virus: Rethinking the Concept of Parasite and Contagion through Contemporary Research in Evolutionary Virology. In: BREANNE, Fahs; MANN, Annika; SWANK, Eric; STAGE, Sarah. (egs). Transforming Contagion: Risky Contacts among Bodies, Disciplines, and Nations. New Brunswick: Rutgers University Press, 2018. p. 42-55.

DAS, Veena. The New Normal as the Old Normal. Deccan Chronicle, 28 de junho de 2020. Disponível em: https://www.deccanchronicle.com/opinion/columnists/280620/veena-das-the-new-normal-in-healthcare-amyth.html. Acesso em: jun. 2020.

DEBAISE, Didier; STENGERS, Isabelle. The Insistence of Possibles: Towards a Speculative Pragmatism. Parse Journal, v. 7, 2017. Disponível em: https://parsejournal.com/article/the-insistence-ofpossibles\%E2\%80\%A8-towards-a-speculative-pragmatism/. Acesso em: maio de 2020.

DELEUZE, Gilles. Lógica do sentido. São Paulo: Perspectiva, 2000.

DELEUZE, Gilles; GUATTARI, Félix. O anti-Édipo: capitalismo e esquizofrenia. São Paulo: Ed. $34,2014$.

DERRIDA, Jacques. O animal que logo sou. São Paulo: Editora UNESP, 2002.

DERRIDA, Jacques. Espectros de Marx. Rio de Janeiro: Relume Dumará, 2002.

ENGELS, Friedrich. A origem da família, da propriedade privada e do Estado. São Paulo: Boitempo Editorial, 2019.

ESCOBAR, Arturo. Encountering Development. Princeton: Pricenton University Press, 1995.

FAN, Yi. Bat Coronaviruses in China. Viruses, v. 11, n. 210, p. 1-14, 2019.

FANG, Lei; KARAKIULAKIS, George, ROTH, Michael. Are patients with hypertension and diabetes mellitus at increased risk for COVID-19 infection?. The Lancet Respiratory Medicine, v. 8, n. 4, e21, 2020.

FOUCAULT, Michel. O pensamento exterior. In: MOTA, Manuel Barros. (org). Estética: literatura e pintura, música e cinema. São Paulo: Forense Universitária, 2009. p. 219-242. (Coleção Ditos e Escritos, v. III).

FOUCAULT, Michel. As palavras e as coisas. São Paulo: Martins Fontes, 2001.

FREUD, Sigmund. Obras completas, volume 4: A interpretação dos sonhos. São Paulo: Companhia das Letras, 2019.

FURTADO, Celso. Brasil: a construção interrompida. Rio de Janeiro: Paz e Terra, 1992.

GALVÃO, Patrícia (Pagu); FERRAZ, Geraldo. A famosa revista. São Paulo: Descaminhos, 2013.

GLISSANT, Edourd. Poetics of Relation. Michigan: The University of Michigan, 1997.

GRANT, Iain. Philosophies of Nature after Schelling. London: Continuum, 2006.

HARAWAY, Donna. Staying with the Trouble. Durham: Duke University Press, 2016.

HARAWAY, Donna. When species meet. Minneapolis: University of Minnesota Press, 2008.

HARAWAY, Donna. The Promises of Monsters: Reproductive Politics for Inappropriate/d Others, In: GROSSBERG, Larry; NELSON, Cary; TREICHLER, Paula. Cultural Studies. New York: Routledge, 1992. p. 295-337.

HARAWAY, Donna. Simians, Cyborgs and Women. Nova York: Routledge 1990.

HAYWARD, Eva. Fingeryeyes: Impressions of Cup Corals. Cultural Anthropology, v. 25, n. 4, p. 577-599, 2010. 
HAYWARD, Eva. When Fish and Frogs Change Gender. Independent Weekly, 3 de agosto de 2011. Disponível: www.indyweek.com/indyweek/when-Kish-and-frogs-change-gender/Content?oid=2626271 . Acesso em: ago. 2020.

HUSSAIN, Mushtaq et al. Structural Variations in Human ACE2 may Influence its Binding with SARS-CoV2 Spike Protein. Journal of Medical Virology, n. 92, p. 1580-1586, 2020.

ICTV. ICTV Master Species List 2019. International Committee on Taxonomy of Viruses, 2019.

KANT, Immanuel. Escritos sobre o Terramoto de Lisboa. Coimbra: Almedina, 2005.

KANT, Immanuel Transición de los princípios metafísicos de la ciência natural a la física (Opus postumum). Madrid: Anthropos/Universidad Autónoma de Madrid, 1991

KECK, Frédéric. Biosecurity and the ecologies of conservation: an anthropology of collecting practices among virus hunters and birdwatchers. Horizontes Antropológicos, Porto Alegre, v. 26, n. 57, p. 93-114, maio/ago. 2020

KELLER, Evelyn Fox. A feeling for the organism. New York: W. H. Freeman, 1984.

KIRBY, Vicky. Quantum Anthropologies. Duke University Press, Durham, 2011.

KRENAK, Ailton. Ideias para adiar o fim do mundo. São Paulo: Companhia das Letras, 2019.

KRZYWOSZYNSKA, Anna; MARCHESI, Greta. Toward a Relational Materiality of Soils. Environmental Humanities, v. 12, n. 1, p. 190-204, 2020.

LATOUR, Bruno. Onde aterrar?: como se orientar politicamente no Antropoceno. Rio de Janeiro: Bazar Tempo, 2020.

LATOUR, Bruno. Ciência em ação: como seguir cientistas sociedade a fora. São Paulo: Editora da UNESP, 2011.

LATOUR, Bruno. Políticas da natureza: como associar as ciências à democracia. São Paulo: Editora da UNESP, 2019.

LEVINAS, Emmanuel. Otherwise Than Being or Beyond Essence. London: Kluwer Academic Publishing, 1998.

LEVI-STRAUSS, Claude. Antropologia Estrutural Dois. Rio de Janeiro: Tempo Brasileiro, 1993.

LYNTERIS, Christos. Human Extinction and the Pandemic Imaginary. Nova York: Routledge, 2020.

LOPES, Eliane. Da sagrada missão pedagógica. Belo Horizonte: Autêntica, 2017.

LOPES, Alice Casimiro. Por um currículo sem fundamentos. Linhas Críticas, v.21, n.45, p. 445-466, mai./ago. 2015.

LOWE, Celia. Viral clouds: Becoming H5N1 in Indonesia. Cultural Anthropology, v. 25, n. 4, p. 625-629, 2010.

LUXEMBURG, Rosa. A acumulação do capital: estudo sobre a Interpretação Económica do Imperialismo. São Paulo: Zahar Editores, 1985.

MACEDO, Elizabeth. A teoria do currículo e o futuro monstro. In: LOPES, Alice Casimiro; SISCAR, Marcos. Pensando a política com Derrida. São Paulo: Cortez, 2018a. p. 153-178.

MACEDO, Elizabeth. Os Estudos Curriculares e o problema do conhecimento: entrevista à Roberto Silva. Educação e Filosofia, v. 32, n. 64, p. 157-184, jan./abr. 2018b.

MACEDO, Elizabeth. Mas a escola não tem que ensinar?: Conhecimento, reconhecimento e alteridade na teoria do currículo. Currículo sem Fronteiras, v. 17, n. 3, p. 539-554, set./dez. 2017.

MACEDO, Elizabeth. Base nacional comum para currículos: direitos de aprendizagem e desenvolvimento para quem?. Educação \& Sociedade, v. 36, n. 133, p. 891-908, out.-dez., 2015.

MACEDO, Eric. Altamira: um ensaio histórico-maquínico sobre a colonização. Tese (Doutorado em Antropologia) - Universidade Federal do Rio de Janeiro, Rio de Janeiro, 2016. 
MARX, Karl. Manuscritos Econômico-filosóficos. São Paulo: Boitempo Editorial, 2010.

MARX, Karl; ENGELS, Friedrich. Manifesto do Partido Comunista. Estudos Avançados, v. 13, n. 34, p. 746, 1998.

MITCHELL, Timothy. Rule of Experts: Egypt, Techno-Politics, Modernity. Berkley: University of California Press, 2002.

MONTGOMERY, David. Dirt: the erosion of civilizations. Berkley: University of California Press, 2008.

MORENO, Camila. A métrica do carbono e as novas equações coloniais. Tese (Doutorado em Ciências em Desenvolvimento, Agricultura e Sociedade) - Universidade Federal Rural do Rio de Janeiro, Seropédica, 2018.

MURRAY, Eleonor; TOMASZEWSKI, Maciej; GUZIK, Tomasz J. Binding of SARS-CoV-2 and angiotensinconverting enzyme 2: clinical implications. Cardiovascular Research, cvaa096, 2020.

MYERS, Natasha. Rendering Life Molecular. Durham: Duke University Press, 2015.

NIN, Anäis. The Diary of Anais Nin (1931-1934). Boston: Houghton Mifflin Harcourt, 1994.

PAPADOPOULOS, Dimitris. Alter-ontologies: Towards a constituent politics in technoscience. Social Studies of Science, v. 41, n. 2, p. 177-201, 2011.

PIGNARRE, Philippe; STENGERS, Isabelle. Capitalist Sorcery: Breaking the Spell. Nova York: Palgrave Macmillan, 2011.

PINAR, William. What is curriculum theory?. Mahwah: Lawrence Erlbaum, 2004.

PINAR, William. Estudos curriculares: ensaios selecionados. São Paulo: Cortez, 2016.

PINTO, Bruna et al. ACE2 Expression is Increased in the Lungs of Patients with Comorbidities Associated with Severe COVID-19. The Journal of Infectious Diseases, n. 222, p. 556-563, 2020.

PLUMWOOD, V. Environmental Culture. London: Routledge, 2002

POVINELLI, Elizabeth. Geontologies. Durham: Duke University Press, 2016.

POVINELLI, Elizabeth. The Empire of Love. Duham: Duke University Press, 2006.

PUAR, Jasbir. The Right to Maim. Duham: Duke University Press, 2017.

ROUSSEAU, Jean-Jacques. Emílio, ou Da Educação. Rio de Janeiro: Bertrand Brasil, 1995.

ROOSSINCK, Marilyn; BAZAN, Edélio. Symbiosis: Viruses as Intimate Partners. Annual Review of Virology, n. 4, p. 123-139, 2017.

SILVA, Tomaz Tadeu. Documentos de identidade. Belo Horizonte: Autêntica, 2007.

SIQUEIRA, Leandro Alberto de Paiva. Ecopolítica: derivas do espaço sideral. Tese (Doutorado em Ciências Sociais) - Pontifícia Universidade Católica, São Paulo, 2015.

STENGERS, Isabelle. A proposição cosmopolítica. Revista do Instituto de Estudos Brasileiros, n. 69, p. 442464, abr. 2018.

SOTOMI, Alice. Dragão confabulando: etnicidade, ideologia e herança cultural através da música para Koto no Brasil. Tese (Doutorado em Música) - Universidade Federal da Bahia, Salvador, 2004.

STEVENS, Hallam. Life out of Sequence. Chicago: University of Chicago Press, 2013.

TANAKA, Pedro. A Crispr-Cas9 System Designed to Introduce Point Mutations into the Human ACE2 Gene to Weaken the Interaction of the ACE2 Receptor with the SARS-CoV-2 S Protein. Preprints, 2020. Disponível em: https://www.preprints.org/manuscript/202005.0134/v1. Acesso em: ago. 2020.

TAUBMAN, Peter. Teaching By Numbers. Nova York: Routledge, 2009.

TSING, Anna. Viver nas ruínas. Brasília: IEB Mil Folhas, 2019.

UJVARI, Stefan Cunha. A história da humanidade contada pelos vírus. São Paulo: Contexto, 2009.

VILLAÇA, Aparecida. Morte na floresta. São Paulo: Todavia, 2020. 
VIVEIROS-DE-CASTRO, Eduardo. A inconstância da alma selvagem e outros ensaios de antropologia. São Paulo: Cosac \& Naify, 2002.

WALLACE, Rob. Pandemia e agronegócio: doenças infecciosas, capitalismo e ciência. São Paulo: Elefante, 2020.

ZHANG, Yong-Zhen; Shi, MANG, HOLMES, Edward C. Using Metagenomics to Characterize an Expanding Virosphere. Cell, v. 172, n. 8, p. 1168-1172, 2018.

YU, Chi-Hua; BUEHLER, Markus J. Sonification based de novo protein design using artificial intelligence, structure prediction, and analysis using molecular modeling. APL Bioengineering, v. 4, 2020.

\section{Correspondência}

Thiago Ranniery: É Professor da Universidade Federal do Rio de Janeiro.

E-mail: t.ranniery@ gmail.com

Texto publicado em Currículo sem Fronteiras com autorização do autor 